海の研究(Oceanography in Japan), 26(1), 1-13, 2017

\title{
－ 2016年度日本海洋学会岡田賞受賞記念論文 -
}

\section{貧栄養海域におけるピコ・ナノプランクトン 栄養動態に関する研究*}

\author{
佐藤 光秀 $^{\dagger}$
}

\section{要 旨}

ピコ・ナノ植物プランクトンは外洋における主要な一次生産者であり, 食物網の起点で ある。本論文ではピコ・ナノ植物プランクトンの組成と分布, 栄養獲得, 被食過程につい て著者らが行ってきた研究の内容と成果を概説する。はじめに, フローサイトメトリーに より代表的なピコ・ナノ植物プランクトングループの分布やサイズ組成を明らかにし，そ の生理的な特徵や環境因子と分布を関連づけた。つづいて, ピコ・ナノ植物プランクトン が多様な群集組成を呈する要因の一つとしてリンや鉄の利用に着目し, 特に, 外洋域で重 要となる有機態リンと有機配位子に結合した鉄の利用について現場での実験をもとに新知 見を得た。また, 植物プランクトン群集を形作る要因としての被食過程に着目し, サイズ 分画から植物プランクトンの被食速度を見積もる手法を開発した。これらの結果から, 外 洋, 特に貧栄養海域におけるピコ・ナノ植物プランクトンの特徵的な栄養獲得戦略を明ら かにした。

キーワード : ピコ・ナノ植物プランクトン，フローサイトメトリー，栄養塩，鉄，混合栄養

\section{1. ピコ・ナノプランクトン}

外洋表層におけるほぼ唯一の一次生産者である植物プ ランクトンの体サイズ範囲は直径にして 10000 倍以上に 及ぶ。世界最小の光合成生物である Prochlorococcus の 細胞径は $0.6 \mu \mathrm{m}$ 程度である (Morel et al., 1993) のに対 し, 珪藻 Ethomodiscus 属の珪藻は直径 2-3 mm, Thalassiothrix 属の珪藻の細胞長は $4 \mathrm{~mm}$ に達する (Round et

\footnotetext{
* 2016 年 9 月 1 日受領; 2016 年 11 月 1 日受理 著作権：日本海洋学会, 2017

†東京大学大学院農学生命科学研究科

干 113-8657 東京都文京区弥生 1-1-1

TEL : 03-5841-5292 FAX : 03-5841-5308

e-mail : asatom@mail.ecc.u-tokyo.ac.jp
}

al., 1990)。また，シアノバクテリア Trichodesmium やプ リムネシウム藻 Phaeocystis は直径 $1 \mathrm{~cm}$ にもおよぶ細胞 群体を形成する (Walsby, 1978; Wang et al., 2011)。漂 泳生態系の生物は摂餌の際に体の位置を固定できないた め, 餌をまるごと取り込む摂餌方式が主流である。この 方式では自身の摂飭器官よりも大きい餌を食べることが できないため, 生産者のサイズはさらに上位の消費者の サイズ組成を規定する要因になる。すなわち, 海洋の一 次生産がぞのようなサイズの生物によって行われている かは漁業生産や生物ポンプの効率を決定する根源的な要 因となっている。プランクトンをサイズにより区分する ことは以上の点から有用であり, 便宜的に相当径で 0.2 から $2 \mu \mathrm{m}$ のものをピコプランクトン, 2 から $20 \mu \mathrm{m}$ のも のをナノプランクトン, 20 から $200 \mu \mathrm{m}$ のものをマイクロ 
プランクトンと呼ぶ。

以上は植物プランクトンを食べる側から見たサイズの 重要性であるが, 植物プランクトン自身にとってサイズ の影響が現れるのは栄養塩の取り込みである。小さい細 胞ほど表面積：体積比が大きくなるため，相対的な栄養 塩取り込みにおいて有利であり, 低濃度の栄養塩環境で も増殖を維持することができる。反面, 大きい細胞はよ り多様な小器官をもつことができる。たとえば，珪藻類 の液胞は溶存物質を貯蔵することができるため, 栄養塩 の供給が大きく変化するような環境で有利である。その ため, 貧栄養海域では一次生産者は圧倒的にピコ・ナノ 植物プランクトンによって占められており (Odate and Maita, 1988), それらから始まる微生物食物網がエネル ギー・物質の主要な転送過程になっている。

外洋におけるピコ・ナノ植物プランクトンの研究は, 1980 年代に端を発し, 分類・生理・生態の各分野で現在 にいたるまで精力的に進められてきた。しかし, 体サイ ズが小さく光学顕微鏡下での観察が難しいこと, 頻繁な アクセスの難しい外洋に分布が集中していること，培養 株の単離や維持が難しいこと, など大型の植物プランク トンと比べ研究障壁が多く，いまだに不明な点が多く残 されている。筆者らは太平洋におけるピコ・ナノ植物プ ランクトンの生態に着目し，これまで研究を行ってきた。 はじめに，ピコ・ナノ植物プランクトン細胞を光学的な 特性の違いから分けられたグループについて，それぞれ の分布特性と, その生理的な特徴との関連を明らかにし た。また，その細胞サイズを規定する環境要因を調べ， 将来的に予測される海水温の上昇が外洋の生態系に及ぼ す影響について考察した。つづいて，外洋において多様 なピコ・ナノ植物プランクトンが共存し, 海域ごとに特 徵的な群集組成を呈する要因について，栄養塩，特にリ ンや鉄の利用と被食過程に着目して研究を進めた。リン や鉄の利用に着目したのは，栄養塩の中で単純な構造で 生理学的にも利用しやすい無機イオンは極めて低い濃度 になるまで利用しつくされていることにより，有機態リ ンや有機配位子に配位した鉄の利用の重要性が高まると 考えたためである。被食過程については，サイズ分画か ら植物プランクトンの被食速度を見積もる手法を開発し た。これらの研究により明らかになったピコ・ナノ植物 プランクトンの生態の一端を以下に紹介する。

\section{2. ピコ・ナノプランクトンの組成と分布}

ピコ・ナノ植物プランクトンは大別すると原核生物と 真核生物に二分される。原核生物の中では，シアノバク テリア (ラン藻) が酸素発生型光合成を行う。ピコ・ナノ サイズのシアノバクテリアとしては，先述の世界最小の 光合成生物である Prochlorococcus およびそれに次いで 小さいSynechococcus (直径 $0.8 \mu \mathrm{m} \sim$ ) のほか, 水中に 溶存する窒素分子を同化すること（窒素固定）ができるナ ノプランクトン Crocosphaera (Zehr et al., 2001) などが 挙げられる。真核生物, 特に原生生物は現在も分類系統 の整理が進行中であり, その中でも光合成生物は様々な 系統に分散して存在している。ピコ・ナノ植物プランク トンはクリプト藻綱，ハプト藻綱 (プリムネシウム藻綱), 緑藻綱, プラシノ藻綱, ペラゴ藻綱などに主に存在する。 また, 珪藻綱や渦鞭毛藻綱の中にもこのサイズ範囲に入 るものがある。元来, これらの種の同定は, 天然サンプ ル，もしくはそこから確立した培養株を電子顕微鏡など で観察することによっていた。しかし，特に外洋種につ いては，培養株の確立が困難なこと，形態的特徵がマイ クロ植物プランクトンに比べてそしいことなどから, 綱 レベルの判別でも多大な労力を要した。1990年代には, 各藻類綱群が特徵的な色素組成を有していることを利用 し, 高速液体クロマトグラフィにより測定した群集全体 の色素組成から藻類綱群の組成を推定する手法が確立さ れ (Mackey et al., 1996)，世界中の海域でのピコ・ナノ 植物プランクトンの組成の理解が飛躍的に進んだ。さら に近年は次世代シークエンサーなど分子生物学的手法の 進化により, 海洋ピコ・ナノ植物プランクトンのより詳 細な組成や新たな分類群 (Not et al., 2007) が次々と明 らかになっている。

これらとは別に, 1980 年代からピコ・ナノ植物プラン クトンの群集解析に用いられている手法にフローサイト メトリーがある (Olson et al., 1985)。これは細胞の懸濁 液にレーザーを当て, 細胞の径や色素量などの情報を細 胞ごとに得る手法である。HPLC ほどの色素分解能はな いが，色素の含量をクロロフィルとフィコエリスリンに 分けて測定することができる。また，蛍光プローブを利 用して, 生理活性を測定したり, 特定の分類群だけを免 
疫化学的に検出したりすることも可能である。フローサ イトメトリーの利点は, 何よりも少量のサンプルから現 場で, ピコ・ナノ植物プランクトンのサイズ組成や打お まかな分類群の組成を測定できる点にある。なお，研究 船上に装置を持ち込めない場合にはサンプルを固定・保 存し，陸上で分析することも可能である(Vaulot et al., 1989 ; Sato et al., 2006)。

著者は 2003 年より研究船にフローサイトメーターを搭 載し，太平洋の全域にわたってピコ・ナノ植物プランク トンの群集構造の解析を行ってきた (Fig. 1)。この結果, すべてのピコ・ナノ植物プランクトン群が明膫な緯度方 向の区分を示すということが明らかになった。Prochlorococcus の分布は南北とも 40 度以下の低緯度海域に限 られていた（Fig. 1 の (a))。Synechococcus はほぼ全海 域に出現したが, 赤道湧昇域や亜寒帯循環域で特に密度 が高かった（Fig. 1の（b)）。真核植物プランクトンは亜 寒帯域で密度が高く(Fig. 1 の (c)), 栄養塩供給による 制御が強く示唆された。また，これらの傾向は概社大西 洋などの他の海域の結果と一致していた。ここで着目さ れるのはフローサイトメトリーにより特に識別可能な 2 群，ナノサイズのシアノバクテリア (以下，ナノシア) バクテリア）とクリプト藻である。

ナノシアノバクテリアは前述の窒素固定性単細胞シア ノバクテリアCrocosphaera を含む群である。ナノシア ノバクテリアの一部が窒素固定を行う (Zehr et al., 2001）ことが明らかになるまで，外洋におけるナノシア ノバクテリアに対する関心は低く, 生態学的・海洋学的 な研究は極めて少なかった (Ishizaka et al., 1994; Neveux et al.. 1999)。著者は太平洋の広域にわたって取 得したフローサイトメトリーのデータからナノシアノバ クテリアの密度を測定し，マッピングした (Sato et al., 2010)。ナノシアノバクテリアは南北とも緯度 $10 ２ 0$ 度 の海域に集中して分布しており, 特に太平洋西部や島嶼 の近傍で高い密度が見られた（Fig. 1 の $(\mathrm{d}))$ 。特に西部 北太平洋に抢ける高密度出現海域の北限は表層のリン酸 塩が検出されはじめる海域 (Hashihama et al., 2009) と ほぼ一致しており，無機リン酸や陸起源物質に依存した 生存戦略を示唆する。

クリプト藻は真核生物でありながらフィコビリン蛋白 を有することで特徵づけられ，特にフィコエリスリンを
含むタイプのものはフローサイトメトリーにより容易に 検出される。クリプト藻は亜寒帯のごく限られた海域で のみ高密度で出現した（Fig. 1の (e))。また, 西部北太 平洋亜寒带域で 2004 年に行われた現場鉄散布実験にお いて, クリプト藻は鉄添加に応答して密度を増加させた。 その後, 溶存鉄濃度が低下して, 他の植物プランクトン 群の生物量が低下していく中でも, クリプト藻は比較的 高い細胞密度を維持していた（Sato et al., 2009)。クリ プト藻は比較的鉄濃度の低いペルー海流域において高い 生物量を示すことが報告されており（DiTullio et al., 2005)，鉄欠乏に耐性があるのかもしれない。

天然群集サンプルにおいて, クリプト藻以外の真核植 物プランクトンは蛍光の情報からそれ以上の細かい分類 群に区分することが難しいため, 便宜的にサイズ情報か らいくつかクラスターに分けるのが通例である。とはい え, 生態系を通じたエネルギー・物質転送の起点のサイ ズ構成を知ることは極めて重要であり (前章参照)，その サイズ構成を決定する因子を知ることは, 気候変動や人 為的な環境改変が海洋生態系に与える影響を予測する上 で必須である。全球的な植物プランクトンのサイズ組成 からの予想では，温暖化にともなう成層の強化，および 栄養塩供給の減少が植物プランクトンの平均サイズを小 さくすると考元れている (Marañón et al., 2001 ; Morán et al., 2010)。しかし，これは極域から亜熱帯までの温度 範囲の観測デー夕から推定された結果であり, 今世紀末 までに予想される表層海水温の上昇幅 $\left(<3{ }^{\circ} \mathrm{C}\right.$, Marinov et al., 2010) に対しても成立するかどうかは疑問である。 また，すでに圧倒的にピコ・ナノ植物プランクトンが優 占している亜熱帯海域で今後どのような変化が起こるか については予想の㘧外である。そこで, 亜熱帯海域のピ コ・ナノ植物プランクトンのみに着目し, その平均細胞 サイズに影響を与える環境因子を明らかにするために, 亜熱帯に特徵的で散乱光強度から細胞サイズを推定でき る 3 群 (Synechococcus, ナノシアノバクテリア，および 真核植物プランクトン) を対象に, 太平洋亜熱帯域表層 における散乱光強度（細胞サイズの指標）データを解析 した（Sato et al., 2015)。その結果，細胞サイズに最も影 響を与えていたのは測定時刻であり，どの群においても 夕方を頂点とする日周サイクルで変動することが見出さ れた。この現象は培養株 (DuRand et al., 2002; Dron et 

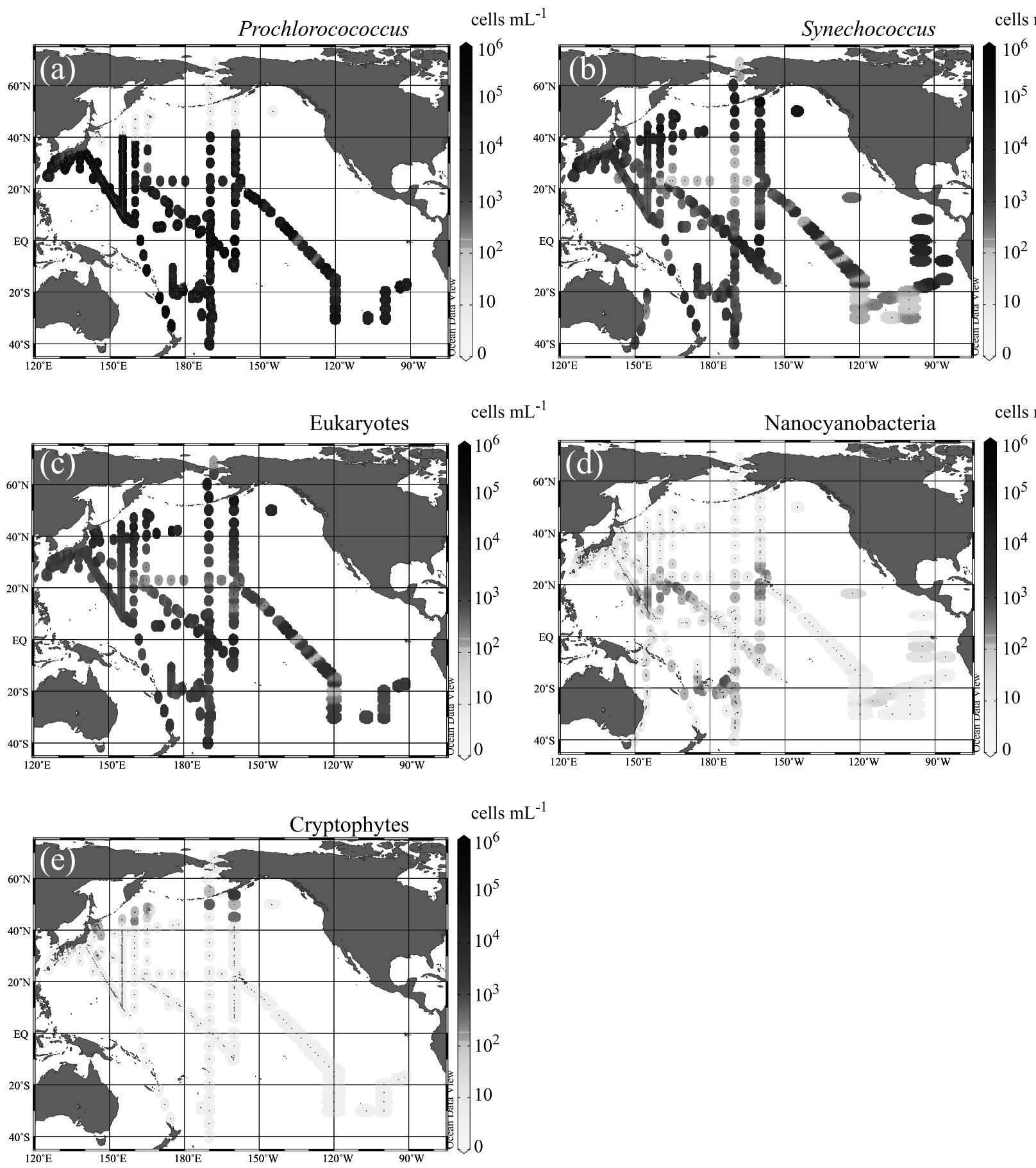

Fig. 1. Cell concentration (cells $\mathrm{mL}^{-1}$ ) of (a) Prochlorococcus, (b) Synechococcus, (c) eukaryotic pico- and nanophytoplankton (excluding cryptophytes), (d) nanocyanobacteria, and (e) cryptophytes at the surface of the Pacific Ocean, as measured by flow cytometry. Data are derived from the research cruises onboard R/V Hakuhomaru, Tansei-maru, Mirai, and Umitaka-maru from 2003 to 2014. Some of the data in this figure are reported by Sato et al. $(2009,2010)$. 
Table 1. Level of significance for the regression of temperature and soluble reactive phosphorus (SRP) concentration against forward light scatter (FSC, index of cell size) of pico- and nanophytoplankton after correcting for diel variations. This table is derived from Sato et al. (2015).

\begin{tabular}{llllll}
\hline & & Single regression & \multicolumn{2}{c}{ Multiple regression } \\
\hline Population & Cruise & Temp. & SRP & Temp. & SRP \\
\hline Synechococcus & KH-08-2 & $>0.1$ & $>0.1$ & & N/A \\
Nano-sized cyanobacteria & KH-08-2 & $>0.1$ & $>0.1$ & & N/A \\
& KH-08-2 & $<0.001$ & $>0.1$ & $<0.001$ & $>0.1$ \\
Pico- and nano-sized eukaryotes & KH-11-10 \& KH-12-3 & $<0.001$ & $<0.05$ & $<0.005$ & $>0.05$ \\
\hline & & & & & \\
\hline
\end{tabular}

al., 2012) や定点観測（Vaulot and Marie, 1999; Olson et al., 2003) でも確認されており, 昼間に光合成により細胞 内に物質を貯蔵し, 夜間にかけて, その物質を利用して 同期的に細胞分裂する現象をとらえたものと考元られる。 この日周サイクルの影響を除去した散乱光強度について, 水温, 緯度, 塩分, 栄養塩濃度などの環境パラメータと の相関を調べたところ, 真核植物プランクトンの散乱光 強度と水温との間または真核植物プランクトンの散乱光 強度とリン酸塩濃度との間のみで有意な相関がみられた (Table 1)。ここで, 特に真核植物プランクトンの散乱 光強度と水温とは強い正の相関 (温度が高いほどサイズ が大きくなる) がみられたことが注目される。これは過 去のデー夕から推定される関係とは逆の結果であった。 将来的な海水温の上昇やそれにともなう成層の強化が, 亜熱帯海域に限って言えば, 植物プランクトン群集全体 の小型化をもたらさない可能性がある。この現象を植物 プランクトンの栄養戦略から説明する試みについては第 5 章で詳述する。

\section{3. ピコ・ナノプランクトンによるリンの利用}

前章でも触れたように，亜熱帯外洋内において，無機 リン酸塩濃度は時空間的に大きく変動していることから, プランクトンの分布を制御する要因の一つとなっている
と考えられる。特に, 北太平洋西部においてリン酸塩濃 度は高感度分析法の検出限界付近にまで低下している (Hashihama et al., 2009)。このような環境において生物 は再生により生じるリン酸塩のほか, 有機態のリンに依 存していると考元られる。海水中の有機態リンはリン原 子周りの分子構造によって分類され, リン酸エステルが 最も主要な形態であり, 強固なリン一炭素結合をもつホス ホン酸がこれに次ぐと考えられている (Young and Ingall, 2010)。しかし，その全容については不明な点が多い。

海洋に打けるリン酸エステルの利用については 1980 年 代から研究があり, その多くはアルカリホスファターゼ というリン酸エステル加水分解酵素の活性に着目したも のであった。アルカリホスファターゼはほとんぞの植物 プランクトンが有しており, リン酸塩欠乏下で発現する ことによりリン久乏に対抗する手段となる。そのため, アルカリホスファターゼ活性はリン酸塩欠乏の指標とし て広く用いられており (Hoppe, 2003), 亜熱帯外洋にお いてはしばしばアルカリホスファターゼの活性の高まり が見られる (Duhamel et al., 2010)。これらの研究では, モデル基質としてリン酸モノエステルが用いられている が，実際には海水中には核酸などの生体分子に由来する ジエステル類も存在していると考えられている。植物プ ランクトンの中でもリン酸ジエステルを唯一のリン源と して増殖できるかどうかは種間で異なる（Yamaguchi, 


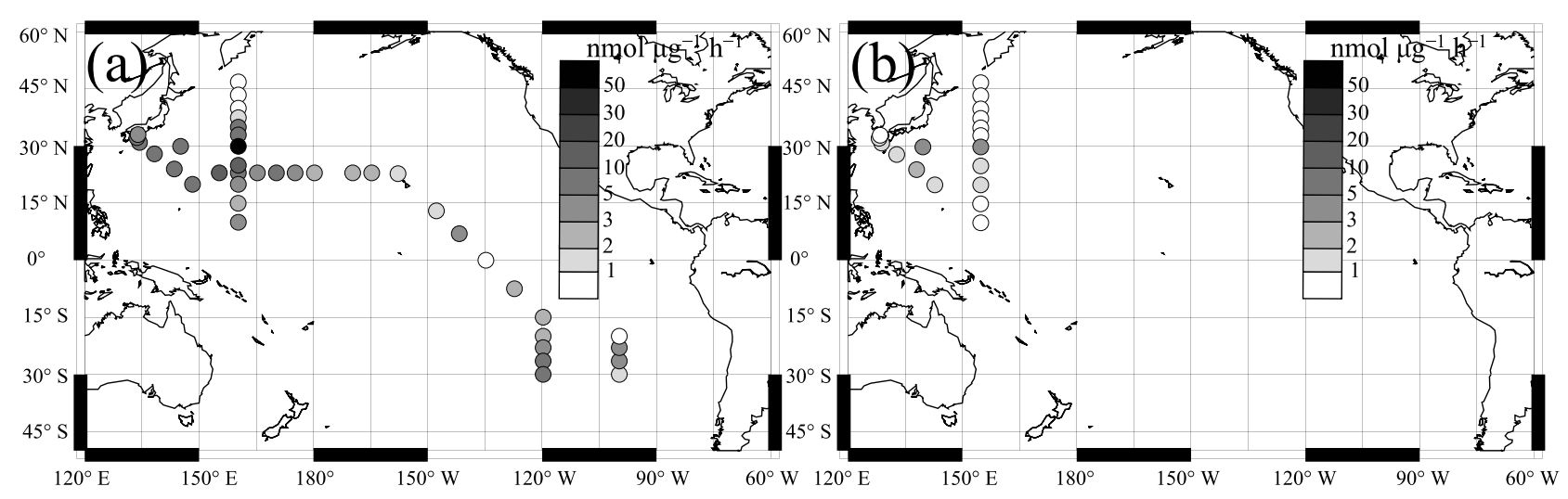

Fig. 2. Activities of phosphate (a) monoesterase and (b) diesterase $\left(\mathrm{nmol} \mathrm{l}^{-1} \mathrm{~h}^{-1}\right)$ at $10 \mathrm{~m}$ of the Pacific Ocean, as normalized by chlorophyll $a$ concentration $\left(\mu \mathrm{g} \mathrm{l}^{-1}\right)$, an index of phytoplankton biomass. Original figure is in Sato et al. (2013).

2005)。このため, ジエステルの利用は貧栄養海域にお ける植物プランクトンの群集構造形成に影響を与えてい ると考えられるが，その加水分解活性を現場で測定した 例はなかった。そこで，著者らは，蛍光基質ビス $(4-メ$ チルウンベリフェリル) リン酸を用いて西部北太平洋に おいてリン酸ジエステルの加水分解を測定した（Sato et al., 2013)。リン酸ジエステルの加水分解速度はリン酸塩 が枯渴した海域で高く, リン酸の欠乏に伴うジエステル の利用が強く示唆された。しかし，その速度はモノエス テルのそれよりも 1 桁以上低かった（Fig. 2) ため, 外洋 表層に打りるン源としての相対的な重要性は高くない と考元られる。複数の基質濃度における活性測定の結果 から求めた潜在的な回転速度は 100 日を超え, リン酸ジ エステルが外洋表層において生物地球化学的に不活性な 画分であることが確認された。溶存 DNA の回転速度が 1 日を下回る (Paul et al., 1987; Brum, 2005) ことを考慮 すると，ジエステルの中には極めて高速で循環している 画分と不活性な画分が混在していると考元られる。

次に解明を進めるべき有機態リンはホスホン酸である が，適切な蛍光基質が市販されていないこと，分解過程 が多段階の反応であり極めて多様な遺伝子が関与してい ることなど克服すべき障壁は多く，研究は未だ初期段階 にある(鈴村ら，2015)。ホスホン酸を唯一のリン源とし て増殖できる植物プランクトンは限定的である。その中 で，窒素固定能を有するシアノバクテリア Trichodesmi- $u m$ に関しては, 単純な分子構造のホスホン酸の分解速 度の測定が試みられている (Karl et al., 2008)。

\section{4. ピコ・ナノプランクトンによる鉄の利用と再生}

植物プランクトンの体を構成する金属元素のうち，鉄 は光合成系や窒素代謝などの生命活動に必須の酵素の中 心金属であり, 突出して要求量が高い。しかし, 高い要 求量に比して海洋表層に招ける鉄イオンの溶解度は低い ために，供給源である陸地から離れた外洋では鉄は不足 しやすい。特に，太平洋東部赤道域，北太平洋亜寒帯 域，そして南大洋の 3 海域は，表層に多量の硝酸塩が残 存しているにもかかわらず植物プランクトン生物量が比 較的低く維持されているため, HNLC (High Nitrate, Low Chlorophyll の略) 海域と呼ばれている。これらの海 域における一次生産の制限要因の一つが鉄不足であるこ とが知られている (Martin et al., 1994; Boyd et al., 2000 ; Tsuda et al., 2003)。HNLC 海域においては，亜熱 帯循環域ほどではないがピコ・ナノ植物プランクトンの 割合は高い。また，これらの海域で行われた鉄散布実験 の結果は，鉄不足による増殖の制限や生理的なストレス がピコ・ナノ植物プランクトンにまで及んでいることを 示している (Suzuki et al., 2005 ; Lance et al., 2007 ; Sato et al., 2009)。亜熱帯循環域の一部では窒素固定が鉄によ る制限を受けている (Grabowski et al., 2008)。したがっ 

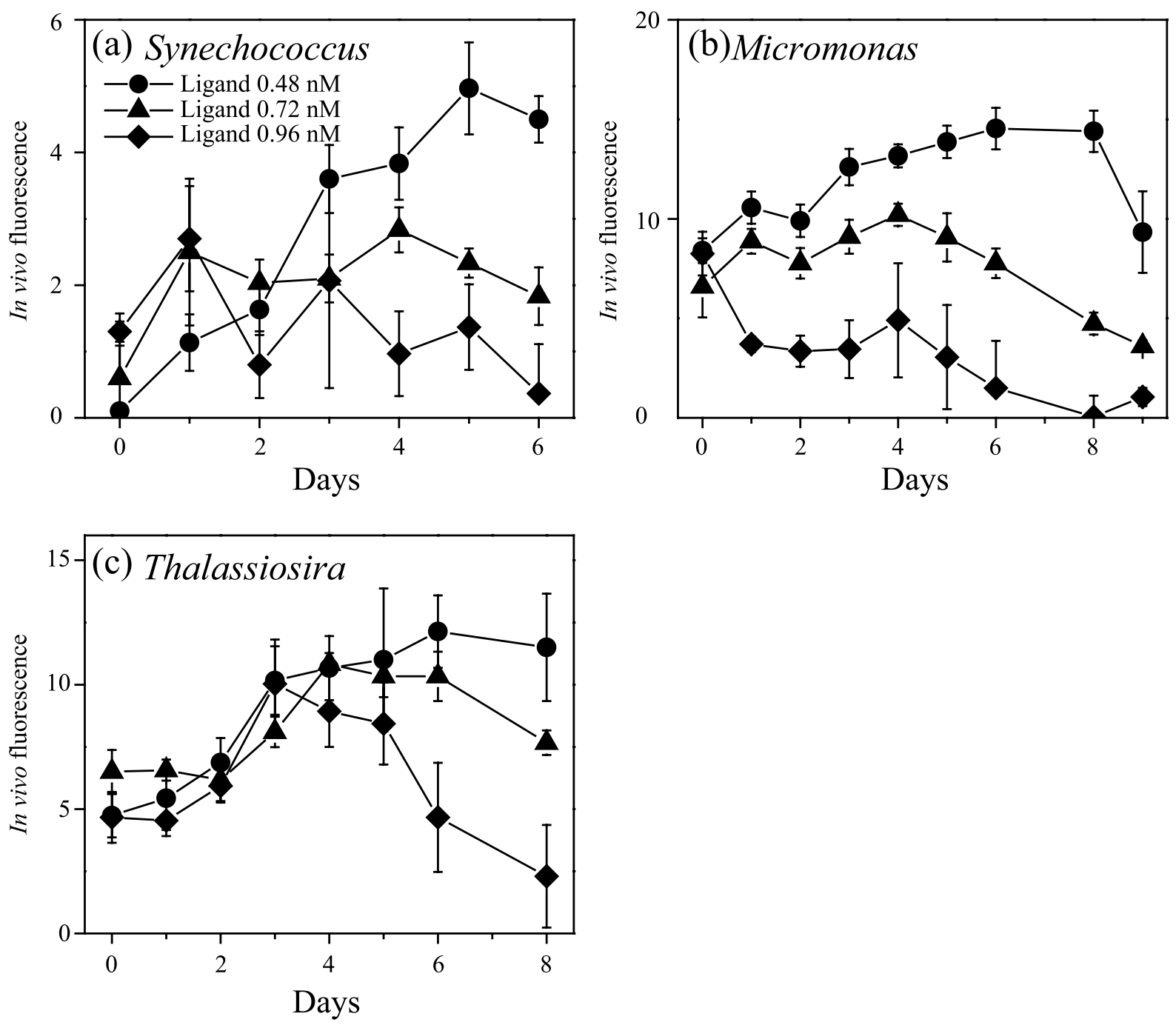

Fig. 3. Temporal changes of in vivo chlorophyll fluorescence showing growth of algal cultures in different seawater media. (a) : Synechococcus sp. (cyanobacterium), (b) Micromonas pusilla (prasinophytes) and (c) : Thalassiosira weissflogii (diatoms). Circles, triangles, and diamonds indicate respectively the values in seawater media before the grazing experiment, those after six days of dark incubation, and those after six days of dark incubation after addition of phytoplankton concentrate. Original figure is in Sato et al. (2007a).

て，窒素やリンが不足しているような海域においても， 鉄が植物プランクトン活動の制限要因の一つとなってい ると考えられる。

外洋表層において，溶存鉄イオンの濃度は一般的に $1 \mathrm{nM}$ を下回るが, 水温・塩分・酸素分圧から計算される 溶解度よりは高いことが多い。これは海水中に存在する 有機物と錯体を形成することにより安定化していること によると考元られている（van den Berg, 1995)。鉄と錯
形成する有機配位子の起源は完全にはわかっていない が, 微生物が鉄欠乏下で放出するシデロフォアと, 植物 プランクトンなどの体内に含まれ, 被食やウィルス感染 の際に海水中に放出されるポルフィリン化合物が候補と してあげられている(Rue and Bruland, 1995)。また, これらの有機配位子は鉄の利用能を変化させることが確 認されている。培養株を用いた実験によると, 原核植物 プランクトン (シアノバクテリア) はシデロフォア錯体を 
効率よく利用し, 真核植物プランクトンはポルフィリン 錯体を相対的によく利用する (Hutchins et al., 1999)。 この観察結果を考慮すると，鉄制限海域において植物プ ランクトンの再生にともない海水中に放出された鉄は, 同時に放出されるポルフィリン化合物の影響により真核 植物プランクトンに優先的に利用され, 植物プランクト ン群集構造の形成に影響をおよぼす，という仮説が成立 する。この仮説は以下の様な小仮説に分解することがで きる。

（1）植物プランクトンの摂餌にともない海水中に鉄 イオンが放出される。

（2）それと同時に鉄の化学形態に影響を及ぼすレべ ルの親和力を有する，十分な化学当量の有機配位 子も放出される。

（3）その配位子と錯形成した鉄イオンは，植物プラ ンクトン種間で利用能の差が見られる。

これら 3 つの小仮説の各々を検証するため, 北太平洋 亜寒帯域の表層海水を用いて, 3 段階の培養実験を行っ た（Sato et al., 2007a)。まず，現場海水を濾過した後に 栄養塩類を加え, ピコ・ナノ植物プランクトンの濃密な 群集を得た。これを，再び同所より採取した現場海水に 加え, 現場の動物プランクトンによる摂餌を増強させた ときの溶存鉄濃度や有機鉄配位子濃度を測定し，コント ロール実験の結果と比較した。ついで, 培養終了後の海 水を濾過し, 藻類培養株を添加して増殖をモニタリング し，海水中の鉄の利用能を調べた。その結果，植物プラ ンクトンの密度を増した系においては植物プランクトン の消費も増えており，それに応じて溶存鉄および有機鉄 配位子の濃度もより大きく増加していた。また，より多 くの配位子が蓄積した海水ほど植物プランクトンの増殖 は抑制され (Fig. 3)，再生された鉄は生物利用能が高く ないことが示唆された。増殖抑制効果は珪藻に対しては シアノバクテリアや緑藻よりも低かったことから，鉄制 限海域における摂饂にともなう鉄再生は植物プランクト ン群集構造を変化させるトリガーになる可能性がある。

\section{5. ピコ・ナノプランクトンの摂餌と被食}

ピコ・ナノ植物プランクトンはナノサイズの鞭毛虫や それよりやや大きい繊毛虫などの動物プランクトンによ
る摂餌を受けている。その摂餌速度は摂餌者と餌粒子の 遭遇確率に依存しているため, 生物を含まない濾過海水 で天然群集を希釈すると, 慨生物の内的増殖速度は変化 しない一方で, 被食速度は減少していく。よって, 希釈 率に対して餌生物のみかけの増殖速度 (=内的増殖速度 と被食速度の差）をプロットすると希釈していない海水 における被食速度が推定可能である。この技術は希釈培 養法 (Landry and Hassett, 1982) と呼ばれ，ピコ・ナノ 植物プランクトンの内的増殖速度と被食速度を簡便に求 める方法として広く用いられている。希釈培養法は「ど の生物が食べられているか」を測定するのには極めて優 れた方法であるが，原理上「どの生物が食べているか」 の情報を得ることができない。これを補完するのが，異 なる孔径のフィルターで濾過して作製した摂慨者の組成 の異なる海水を培養し, 餌生物の増殖を比較することに よってそれぞれの摂餌者の寄与を見積る分画培養法であ る。

しかし, 分画培養法は用いるフィルターの孔径と生物 学的な分類のサイズの境界が必ずしも一致しないことや, フィルターの孔径よりも大きい生物もすり抜けることが あること（Stockner et al., 1990）などにより，厳密なサ イズ分画が不可能であり, 結果の解釈は定性的なものに なりがちである。そこで，筆者はむしろ分画が不完全な ことを利用し，摂餌者の組成が異なる各海水について重 回帰分析をすることにより，摂餌者の各群による摂餌へ の寄与を見積もる手法を開発した (Sato et al., 2007b)。 海水を 2 から $200 \mu \mathrm{m}$ の異なる目合のフィルターで濾過 し, 動物プランクトンの組成の異なる複数の海水を作製 した。理想的にはある目合を境にある種のプランクトン がまったくいないか元の海水と同じだけ存在するかにな るが，実際には分画が不完全なことにより，画分ごとに なだらかに動物プランクトン密度の異なる海水が作製さ れる。従属栄養性ナノ鞭毛虫と繊毛虫ではその平均細胞 サイズが異なるため, 画分ごとにこれら 2 種の動物プラ ンクトンの比も異なる海水ができる。これらの海水をそ れぞれ培養し, 各画分における植物プランクトンの見た 目の増殖速度および動物プランクトン密度を測定した。 見かけの増殖速度は内的増殖速度と各動物プランクトン から受ける摂饂速度の線型結合であるとの仮定のもと重 回帰分析を行うことで，それぞれのパラメー夕を推定し 
た。その結果は過去培養株などを用いて得られた濾水速 度の範囲内にあり, 手法の妥当性が裏付けられた。しか し一方で, 回帰が有意でない場合も見られた。これは, この二者のみを植物プランクトンの摂餌者として考慮す るだけでは不完全である可能性を示唆している。たとえ ば，顕微鏡下での観察では植物プランクトンとして計数 されてしまう混合栄養生物の影響が考えられる。

混合栄養生物とは，無機炭素から有機炭素を同化する 独立栄養と, 外部から有機物そのものを同化する従属栄 養を一つの生物体の中で両立する生物のことである。ほ とんどの生物, 特に植物プランクトンは何らかの溶存有 機物を細胞外から取り込むことができる広義の混合栄養 生物であるが, ここでは混合栄養における従属栄養を粒 子態物質の取り込みに限るという狭い意味での定義を用 いる(Flynn et al., 2013)。植物プランクトンにおける粒 子食は, 内湾に抢ける渦鞭毛藻類の大量発生の機構とし て古くから知られている (Burkholder et al., 2008)。し かし, 外洋の比較的小型のナノプランクトン, 時にピコ プランクトンに打いても広くみられる現象であることが 明らかになったのは比較的近年のことである (Zubkov and Tarran, 2008; Sanders and Gast, 2012)。

混合栄養生物は炭素のほか, 窒素やリン, 鉄といった 栄養塩をより小さい生物が取り込んだものを利用するこ とでサイズによる不利を克服することができる一方, 細 胞内に光合成器官と摂餌器官を同時にもたなければなら ず，資源の投資が大きくなるという不利な点も負ってい る。しかし, このような機構は栄養塩が枯渴する外洋表 層において比較的大型の植物プランクトンが増殖を維持 する上で有利であると考えられており, 数值モデルに よって水柱の安定が混合栄養生物の優位をもたらすこと が示されている (Mitra et al., 2014)。フィールドにおけ る観測や測定においても, 外洋表層における植物プラン クトンによる摂餌は数多く観察されている (Zubkov and Tarran, 2008; Hartmann et al., 2012)。また, 筆者らの 中部太平洋に拧ける観測では, 粒子食を行うナノ植物プ ランクトンの比率は亜熱帯循環域で他の海域より高く, リン酸塩濃度と負の相関を示した (Sato et al., in press)。 これらの結果は, 混合栄養という戦略が貧栄養海域での 生存に有効である可能性を示唆するものである。また, 第 2 章で紹介したように, ピコ・ナノ植物プランクトン
の平均細胞サイズが熱帯・亜熱帯においてリン酸塩濃度 と負の相関を示す（Sato et al., 2015）ことも，比較的細 胞サイズの大きい混合栄養生物の寄与の変化という観点 から説明することも可能である。混合栄養生物は摂餌器 官を細胞内にもたなければならないため, 完全独立栄養 生物と比較して細胞サイズが大きくなるためである。

\section{6. おわりに}

本論文においては, ピコ・ナノプランクトン, 特に外 洋におけるピコ・ナノ植物プランクトンについて, 組成 と現存量, 栄養塩の利用と増殖, 被食という 3 つの観点 から，その生態系における重要性の一端を明らかにする ために筆者らが行ってきた研究を関連研究とともに紹介 した。

太平洋の広汎な海域において, フローサイトメトリー を用いて得られたピコ・ナノ植物プランクトンの群集構 造を示した。既往研究で報告されていたグループに加 え, 比較的限られた地域に出現するナノシアノバクテリ アやクリプト藻といったグループの水平分布からは, $2 つ$ のグループの特徵的な生存戦略が強く示唆された。より 分類群を詳細に解析するためには, 今後は分子生物学的 手法の導入がますます主流になっていくであろう。しか し, 船上で即時に高時空間分解能でピコ・ナノ植物プラ ンクトンの群集構造を知ることのできるフローサイトメ トリーは今後も重宝されるであろう。

リン酸塩の枯渴は微生物によるモノエステルの加水分 解酵素の活性を高めることは広く知られていたが, ジエ ステルの加水分解酵素の活性も同時に高まることも明ら かになった。しかし, ジエステル加水分解速度はモノエ ステルのそれと比べると 1 桁以上低く, 核酸のような特 殊な構造のものを除いて, ジエステルは外洋表層におい ては生物的に不活性な画分であることが示唆された。

鉄の不足が生物生産を制限するような海域では, 再生 により海水中に供給される鉄が重要な役割を担っている。 ピコ・ナノ植物プランクトンの被食にともなって海水中 に放出される鉄は同時に海水中に放出される配位能をも つ有機物の影響を受け, 植物プランクトンによるその利 用能は無機溶存鉄と比べて低いことが明らかになった。 しかも, その有機物による利用能の低下は, 珪藻よりも 
シアノバクテリアや緑藻において顕著に現れ，再生鉄の 利用能が植物プランクトン群集構造に影響をおよぼす可 能性が示唆された。

プランクトン食物網構造を定性的に理解する手法とし て用いられてきた分画培養法に重回帰分析を組み合わせ ることで, 生物量が比較的多い沿岸域においては, 動物 プランクトングループ別に摂餌速度を定量的に見積もる ことができることがわかった。実際に現場に適用した場 合，回帰が有意でない場合があり，これを説明する要因 として混合栄養生物の存在が示唆された。混合栄養生物 は外洋においても重要なコンポーネントであり, 栄養塩 の欠乏が強くなるほどその重要性を増す可能性がある。 混合栄養生物は栄養塩濃度が極めて低い海域で比較的大 型のナノ植物プランクトンが生物量を維持している機構 を説明するかもしれない。今後，この仮説を検証するた めに, 外洋プランクトン生態系における混合栄養生物の 役割を定量的に評価していく必要がある。

\section{謝 辞}

このたび，名誉と伝統ある日本海洋学会岡田賞に選出 いただき，誠に光栄に存じます。推薦ならびに選考に携 わられたすべての先生方および委員の皆様には厚く御礼 申し上げます。今回このような栄誉をいただくに值する 研究成果は当然独力では成し遂げることはかなわず，多 数の皆様の有形無形のお力添えによるものです。東京大 学の古谷研教授には学生時代においては指導教員とし て, 研究者・海洋学者としての基礎の基礎からご指導い ただき，現職においては上司そして共同研究者としてこ れまで目の覚めるような議論と啓発をいただいてきまし た。特に研究活動における健全な批判的精神は今でも, そしてこれからも私にとっては座右のものとなりました。 深く感謝申し上げます。長崎大学の武田重信教授には微 量金属測定に必須の洗浄・サンプリング・測定の技術か ら論文の添削にいたるまで, 研究者としての土台を授け ていただきました。心より御礼申し上げます。

東京海洋大学の橋濱史典博士, 海洋研究開発機構の塩 崎拓平博士とはこれまで数多くの共同研究とデー夕の交 換を通じて時には闊達に, 時には精緻に, 議論を重ねる ことができました。お二方に加え, 長崎大学の近藤能子
博士, 水産研究 - 教育機構の北島聡博士, 児玉武稔博士 をはじめとする東京大学水圈生物環境学研究室のメン バーとの日々は私の研究者としての欠くことのできない 一部分となっております。

私の研究活動の多くは研究船の上で行われたもので す。海洋研究開発機構白鳳丸, 淡青丸, みらい, 東京海 洋大学海鷹丸, 長崎大学長崎丸, ワシントン大学 Thomas G. Thompson 号, 水産研究 - 教育機構若鷹丸の士官・ 船員の皆様には観測・研究の円滑な進行のため多大なご 協力をいただきました。また, 500 日を超える乗船生活を ともに過ごした乗船研究者の皆様のご協力も忘れること はできません。東京大学大気海洋研究所観測研究推進室 および株式会社マリン・ワーク・ジャパンの皆様による 観測支援には心より感謝申し上げます。

研究とは離れた環境でくつろぎの時間をくれるすべて の友人たちは，研究に新たな気持ちで向き合うための癒 しとインスピレーションを与えてくれることに感謝して おります。そして私を大学院博士課程まで進学させてい ただいた両親と家族には，この年龄になってあらためて 感謝と尊敬の念が増す次第です。

\section{References}

Boyd, P. W., A. J. Watson, C. S. Law, E. R. Abraham, T. Trull, R. Murdoch, D. C. E. Bakker, A. R. Bowie, K. O. Buesseler, H. Chang, M. Charette, P. Croot, K. Downing, R. Frew, M. Gall, M. Hadfield, J. Hall, M. Harvey, G. Jameson, J. LaRoche, M. Liddicoat, R. Ling, M. T. Maldonado, R. M. McKay, S. Nodder, S. Pickmere, R. Pridmore, S. Rintoul, K. Safi, P. Sutton, R. Strzepek, K. Tanneberger, S. Turner, A. Waite, and J. Zeldis (2000): A mesoscale phytoplankton bloom in the polar Southern Ocean stimulated by iron fertilization. Nature, 407, 695-702.

Brum, J. R. (2005) : Concentration, production and turnover of viruses and dissolved DNA pools at Stn ALOHA, North Pacific Subtropical Gyre. Aquat. Microb. Ecol., 41, 103-113.

Burkholder, J. M., P. M. Glibert, and H. M. Skelton (2008) : Mixotrophy, a major mode of nutrition for harmful algal species in eutrophic waters. Harmful Algae, 8, 77-93.

DiTullio, G. R., M. E. Geesey, J. M. Maucher, M. B. Alm, S. F. Riseman, and K. W. Bruland (2005) : Influence of iron on algal community composition and physiological status in the Peru upwelling system. Limnol. Oceanogr., 50, 1887-1907.

Dron, A., S. Rabouille, P. Claquin, B. Le Roy, A. Talec, and A. Sciandra (2012) : Light-dark (12:12) cycle of carbon and nitrogen metabolism in Crocosphaera watsonii WH8501: relation to the cell cycle. Environ. Microbiol., 14, 967-981.

Duhamel, S., S. T. Dyhrman, and D. M. Karl (2010) : Alkaline phosphatase 
activity and regulation in the North Pacific Subtropical Gyre. Limnol. Oceanogr., 55, 1414-1425.

DuRand, M. D., R. E. Green, H. M. Sosik, and R. J. Olson (2002) : Diel variations in optical properties of Micromonas pusilla (Prasinophyceae). $J$. Phycol., 38, 1132-1142.

Flynn, K. J., D. K. Stoecker, A. Mitra, J. A. Raven, P. M. Glibert, P. J. Hansen, E. Granéli, and J. M. Burkholder (2013): Misuse of the phytoplankton-zooplankton dichotomy: the need to assign organisms as mixotrophs within plankton functional types. J. Plankt. Res., 35, 3-11.

Grabowski, M. N. W., M. J. Church, and D. M. Karl (2008) : Nitrogen fixation rates and controls at Stn ALOHA. Aquat. Microb. Ecol., 52, 175183.

Hartmann, M., C. Grob, G. A. Tarran, A. P. Martin, P. H. Burkill, D. J. Scanlan, and M. V. Zubkov (2012): Mixotrophic basis of Atlantic oligotrophic ecosystems. Proc. Natl. Ac. Sci., 109, 5756-5760.

Hashihama, F., K. Furuya, S. Kitajima, S. Takeda, T. Takemura, and J. Kanda (2009): Macro-scale exhaustion of surface phosphate by dinitrogen fixation in the western North Pacific. Geophys. Res. Lett., 36, doi : $10.1029 / 2008 \mathrm{~g} 1036866$.

Hoppe, H. G. (2003) : Phosphatase activity in the sea. Hydrobiologia, 493, $187-200$.

Hutchins, D. A., A. E. Witter, A. Butler, and G. W. Luther III (1999) : Competition among marine phytoplankton for different chelated iron species. Nature, 400, 858-861.

Ishizaka, J., H. Kiyosawa, K. Ishida, K. Ishikawa, and M. Takahashi (1994) : Meridional distribution and carbon biomass of autotrophic picoplankton in the central north Pacific Ocean during late northern summer 1990. Deep-Sea Res. I, 41, 1745-1766.

Karl, D. M., L. Beversdorf, K. M. Björkman, M. J. Church, A. Martinez, and E. F. DeLong (2008): Aerobic production of methane in the sea. Nature Geoscience, 1, 473-478.

Lance, V. P., M. R. Hiscock, A. K. Hilting, D. A. Stuebe, R. R. Bidigare, W. O. Smith, and R. T. Barber (2007) : Primary productivity, differential size fraction and pigment composition responses in two Southern Ocean in situ iron enrichments. Deep-Sea Res. I, 54, 747-773.

Landry, M. R., and R. P. Hassett (1982): Estimating the grazing impact of marine micro-zooplankton. Mar. Biol., 67, 283-288.

Mackey, M. D., D. J. Mackey, H. W. Higgins, and S. W. Wright (1996): CHEMTAX - a program for estimating class abundances from chemical markers: application to HPLC measurements of phytoplankton. Mar. Ecol. Prog. Ser., 144, 265-283.

Marañón, E., P. M. Holligan, R. Barciela, N. González, B. Mouriño, M. J. Pazó, and M. Varela (2001): Patterns of phytoplankton size structure and productivity in contrasting open-ocean environments. Mar. Ecol. Prog. Ser., 216, 43-56.

Marinov I., S. C. Doney, and I. D. Lima (2010) : Response of ocean phytoplankton community structure to climate change over 21 st century: partitioning the effects of nutrients, temperature and light. Biogeosciences, 7, 3941-3959.

Martin, J. H., K. H. Coale, K. S. Johnson, S. E. Fitzwater, R. M. Gordon, S. J. Tanner, C. N. Hunter, V. A. Elrod, J. L. Nowicki, T. L. Coley, R. T. Barber, S. Lindley, A. J. Watson, K. Van Scoy, C. S. Law, M. I. Liddicoat, R. Ling, T. Stanton, J. Stockel, C. Collins, A. Anderson, R. Bidigare, M. Ondrusek, M. Latasa, F. J. Millero, K. Lee, W. Yao, J. Z. Zhang, G. Friederich, C. Sakamoto, F. Chavez, K. Buck, Z. Kolber, R. Greene,
P. Falkowski, S. W. Chisholm, F. Hoge, R. Swift, J. Yungel, S. Turner, P. Nightingale, A. Hatton, P. Liss, and N. W. Tindale. (1994) : Testing the iron hypothesis in ecosystems of the equatorial Pacific Ocean. Nature, 371, 123-129.

Mitra, A., K. J. Flynn, J. M. Burkholder, T. Berge, A. Calbet, J. A. Raven, E. Graneli, P. M. Glibert, P. J. Hansen, D. K. Stoecker, F. Thingstad, U. Tillmann, S. Vage, S. Wilken, and M. V. Zubkov (2014): The role of mixotrophic protists in the biological carbon pump. Biogeosciences, 11, 995-1005.

Morán, X. A. G., Á. López-Urrutia, A. Calvo-Díaz, and W. K.W. Li (2010) : Increasing importance of small phytoplankton in a warmer ocean. Glob. Change. Biol., 16, 1137-1144.

Morel, A., Y.-W. Ahn, F. Partensky, D. Vaulot, and H. Claustre (1993): Prochlorococcus and Synechococcus: a comparative study of their size, pigmentation and related optical properties. J. Mar. Res., 51, 617-649.

Neveux, J., F. Lantoine, D. Vaulot, D. Marie, and J. Blanchot (1999): Phycoerythrins in the southern tropical and equatorial Pacific Ocean: Evidence for new cyanobacterial types. J. Geophys. Res., 104, 3311-3321.

Not, F., K. Valentin, K. Romari, C. Lovejoy, R. Massana, K. Tobe, D. Vaulot, and L. K. Medlin (2007) : Picobiliphytes: a marine picoplanktonic algal group with unknown affinities to other eukaryotes. Science, 315, $253-255$.

Odate, T., and Y. Maita (1988): Regional variation in the size composition of phytoplankton communities in the western North Pacific Ocean spring 1985. Biol. Oceanogr., 6, 65-78.

Olson, R. J., A. Shalapyonok, and H. M. Sosik (2003) : An automated submersible flow cytometer for analyzing pico- and nanophytoplankton: FlowCytobot. Deep-Sea Res. I, 50, 301-315.

Olson, R. J, D. Vaulot, and S. W. Chisholm (1985) : Marine phytoplankton distributions measured using shipboard flow cytometry. Deep-Sea Res., 32, 1273-1280.

Paul, J. H., W. H. Jeffrey, and M. F. Deflaun (1987) : Dynamics of extracellular DNA in the marine environment. Appl. Environ. Microbiol., 53, $170-179$.

Round, F. E., R. M. Crawford, and D. G. Mann (1990) : The Diatoms : Morphology and Biology of the Genera. Cambridge University Press, Cambridge.

Rue, E. L., and K. W. Bruland (1995): Complexation of iron (III) by natural organic-ligands in the central North Pacific as determined by a new competitive ligand equilibration adsorptive cathodic stripping voltammetric method. Mar. Chem., 50, 117-138.

Sanders, R. W., and R. J. Gast (2012) : Bacterivory by phototrophic picoplankton and nanoplankton in Arctic waters. FEMS Microbiol. Ecol., $82,242-253$.

Sato, M., F. Hashihama, S. Kitajima, S. Takeda, and K. Furuya (2010): Distribution of nano-sized Cyanobacteria in the western and central Pacific Ocean. Aquat. Microb. Ecol., 59, 273-282.

Sato, M., T. Kodama, F Hashihama, and K. Furuya (2015) : The effects of diel cycles and temperature on size distributions of pico- and nanophytoplankton in the subtropical and tropical Pacific Ocean. Plankton Benthos Res., 10, 26-33.

Sato, M., R. Sakuraba, and F. Hashihama (2013): Phosphate monoesterase and diesterase activities in the North and South Pacific Ocean. Biogeosciences, 10, 7677-7688.

Sato, M., T. Shiozaki, and F. Hashihama (in press): Distribution of mix- 
otrophic nanoflagellates along the latitudinal transect of the central North Pacific. J. Oceanogr., doi : 10.1007/s10872-016-0393-x.

Sato, M., S. Takeda, and K. Furuya (2006): Effects of long-term sample preservation on flow cytometric analysis of natural populations of pico- and nanophytoplankton. J. Oceanogr., 62, 903-908.

Sato, M., S. Takeda, and K. Furuya (2007a) : Iron regeneration and organic iron (III) -binding ligand production during in situ zooplankton grazing experiment. Mar. Chem., 106, 471-488.

Sato, M., S. Takeda, and K. Furuya (2009) : Responses of pico- and nanophytoplankton to artificial iron infusions observed during the second iron enrichment experiment in the western subarctic Pacific (SEEDS II ). Deep-Sea Res. II, 56, 2745-2754.

Sato, M., T. Yoshikawa, S. Takeda, and K. Furuya (2007b): Application of the size-fractionation method to simultaneous estimation of clearance rates by heterotrophic flagellates and ciliates of pico- and nanophytoplankton. J. Exp. Mar. Biol. Ecol., 349, 334-343.

Stockner, J. G., M. E. Klut, and W. P. Cochlan (1990): Leaky filters : A warning to aquatic ecologists. Can. J. Fish. Aquat. Sci., 47, 16-23.

Suzuki, K., A. Hinuma, H. Saito, H. Kiyosawa, H. Liu, T. Saino, and A. Tsuda (2005): Responses of phytoplankton and heterotrophic bacteria in the northwest subarctic Pacific to in situ iron fertilization as estimated by HPLC pigment analysis and flow cytometry. Prog. Oceanogr., 64, 167-187.

鈴村昌弘，塚崎あゆみ，橋濱史典，佐藤光秀，梅澤有 (2015) : 貧栄養海域 のリンの循環過程と解析手法. 地球環境, 20, 77-88.

Tsuda, A., S. Takeda, H. Saito, J. Nishioka, Y. Nojiri, I. Kudo, H. Kiyosawa, A. Shiomoto, K. Imai, T. Ono, A. Shimamoto, D. Tsumune, T. Yoshimura, T. Aono, A. Hinuma, M. Kinugasa, K. Suzuki, Y. Sohrin, Y. Noiri, H. Tani, Y. Deguchi, N. Tsurushima, H. Ogawa, K. Fukami, K. Kuma, and T. Saino (2003): A mesoscale iron enrichment in the western Subarctic Pacific induces a large centric diatom bloom. Science, 300, 958-961.

van den Berg, C. M. G. (1995) : Evidence for organic complexation of iron in seawater. Mar. Chem., 50, 139-157.

Vaulot, D., C. Courties, and F. Partensky (1989) : A simple method to preserve oceanic phytoplankton for flow cytometric analyses. Cytometry, $10,629-635$.

Vaulot, D., and D. Marie (1999): Diel variability of photosynthetic picoplankton in the equatorial Pacific. J. Geophys. Res., 104, 3297.

Walsby, A. E. (1978): The properties and buoyancy-providing role of gas vacuoles in Trichodesmium Ehrenberg. British. Phycol. J., 13, 103-116.

Wang, X. D., Y. Wang, and W. O. Smith (2011): The role of nitrogen on the growth and colony development of Phaeocystis globosa (Prymnesiophyceae). Eur. J. Phycol., 46, 305-314.

Yamaguchi, H. (2005) : Utilization of phosphate diester by the marine diatom Chaetoceros ceratosporus. J. Plankt. Res., 27, 603-606.

Young, C., and E. Ingall (2010): Marine dissolved organic phosphorus composition: Insights from samples recovered using combined electrodialysis/reverse osmosis. Aquat. Geochem., 16, 563-574.

Zehr, J. P., J. B. Waterbury, P. J. Turner, J. P. Montoya, E. Omoregie, G. F. Steward, A. Hansen, and D. M. Karl (2001) : Unicellular cyanobacteria fix $\mathrm{N}_{2}$ in the subtropical North Pacific Ocean. Nature, 412, 635638.

Zubkov, M. V., and G. A. Tarran (2008) : High bacterivory by the smallest phytoplankton in the North Atlantic Ocean. Nature, 455, 224-226. 


\title{
Studies on the dynamics of pico- and nanophytoplankton in oligotrophic oceans in relation to nutrient availability
}

\author{
Mitsuhide Sato*
}

\begin{abstract}
Pico- and nanophytoplankton are important primary producers in the open ocean and form the foundations of food webs. The author has studied the composition and spatial distribution, nutrient acquisition and grazing loss of pico- and nanophytoplankton. First, the spatial distribution and size composition of pico- and nanophytoplankton have been revealed by flow cytometry and related with their physiological characteristics and environmental factors. Second, the author focused on the utilization of phosphorus and iron, as a driving factor of pico- and nanophytoplankton community formation, with special emphasis on organic phosphorus compounds and organic iron complexes, and obtained some novel insights from field experiments. Third, a new methodology was investigated to estimate the grazing rates of different microzooplankton groups on pico- and nanophytoplankton based on the size-fractionation method. These results were used to study the characteristic nutrient acquisition strategies of pico- and nanophytoplankton in the open oligotrophic ocean.
\end{abstract}

Key words : Pico- and nanophytoplankton, flow cytometry, nutrients, iron, mixotrophy

(Corresponding author's e-mail address : asatom@mail.ecc.u-tokyo.ac.jp)

(Received 1 September 2016 ; accepted 1 November 2016)

(Copyright by the Oceanographic Society of Japan, 2017)

\footnotetext{
* Graduate School of Agricultural and Life Sciences, The University of Tokyo

Yayoi 1-1-1, Bunkyo-ku, Tokyo, 113-8657, Japan

TEL: +81358415292 FAX: +81358415308

e-mail: asatom@mail.ecc.u-tokyo.ac.jp
} 